\title{
Mapping and Payment on Tangerang to West Jakarta's Toll Road's Gate Using Non-Determenistic Finite State Automata
}

\author{
Deka Primatio D. ${ }^{1}$, Farrel Irs yad F. ${ }^{2}$, Kharansyah Tawaddu S. ${ }^{3}$, M. Rizky Zaldi ${ }^{4}$, Raul Andrian ${ }^{5}$ \\ \{deka.primatio@student.umn.ac.id ${ }^{1}$, farrel.irsyad@student.umn.ac.id ${ }^{2}$, \\ kharansyah.tawaddu@student.umn.ac.id ${ }^{3}$, mochamad.rizky@student.umn.ac.id ${ }^{4}$, \\ raul.andrian@student.umn.ac.id $\left.{ }^{5}\right\}$ \\ Faculty of Information and Technology, Universitas Multimedia Nusantara, Jl. Scientia \\ Boulevard, Gading Serpong, Tangerang, Banten, Indonesia $15527_{1,2,3,4,5}$
}

\begin{abstract}
In this research, the concept of Non-Deterministic Finite Automata is used for mapping and simulating the payment system for the Tangerang - West Jakarta toll road. Currently, toll road construction is being intensively developed, because it is one of the government's flagship programs, namely infrastructure development. Tolls in Indonesia apply a uniform fare system without priorit izing the calculation of vehicle mileage, the main disadvantage of this system is that it does not take into account the possibility of attracting users who travel short distances by making toll rate differences. Therefore, this study designed a mapping with payment system based on the calculation of the distance traveled by the vehicle from the toll gate in to the toll gate out. The implementation in the form of simulations is carried out using a raptor in the form of a conceptual and systematic flowchart program, and the simulation works effectively, starting from the balance scan to the suitability of the toll gate exit output and the distance traveled. The concept of Non-Deterministic Finite Automata can be a method for creating payment systems and mapping toll gate. From the results of testing with various scenarios, the application can run well with results that are as expected. With this research, the toll road gate payment system will be more equitable by having a system to calculate toll rates based on the distance traveled by vehicles.
\end{abstract}

Keywords: Jalan Tol, Automata, Non-Deterministic Finite Automata, T angerang-Jakarta

\section{Introduction}

Making simulations to describe the process is an alternative to making a real system that requires large resources. Logical simulations can use the field of information science, and that is Finite State Automata. The application has been carried out in many fields [1], including transportation, especially toll roads. Toll Roads are roads that are designed to be freeway. The presence of the toll road is expected to increase comfort and shorten travel time compared to the road outside the toll road which is filled with various types of vehicles. However, this comfort is often not felt by toll road users in big cities. This is caused by flat fare. In a flat fare structure, rates are imposed regardless of the distance traveled. Flat fare offer a number of benefits that have been widely introduced, es pecially the ease in collecting fees, es pecially the ease in collecting costs 
within the Toll. The main dis advantage of theflat fare systemis that it does not take into account the possibility of attracting users who travel short distances by making a fare difference. In general, flat fare are usually applied in a reasonable manner, ie the length of travel for most toll users is the same [2].

Based on [3], the volume of vehicle traffic pas sing through the Tangerang-Jakarta toll road in 2014 amounted to 119.8 million transactions that have been recorded. Meanwhile, the highest volume was in the Jakarta Inner Ring Road toll road in 2013 of 208.3 million. The volume of vehicles in Indonesia has fluctuated, so clear observations are needed regarding toll road transactions and uses.

The development of facilities and infrastructures on the toll road in the form of planning, operational design, and research requires the value of Annual Average Daily Traffic (AADT), a survey of traffic volume for one year (365 days) will require a large amount of time and cost, so a prediction is made The AADT uses the previous year's traffic data [4]. Based on preliminary observations that there are no studies that observe traffic patterns and look for expansion factors to determine AADT prediction values and are supported by data obtained from PT. Jas amarga (Persero) Tangerang-Jakarta branch, for that research conducted focused on the Tangerang toll road to the West Jakarta tollroad.

In 2016, a research [5] was conducted, regarding the mapping of motorized parking systems. However, research has not examined about payment. In 2017, a study was conducted [6] on the toll rates identification system based on distance per kilometer. In another study in 2018 concerning ideal toll rates using the Ability to Pay (ATP) method [7], it was found that the use of toll rates withdrawals based on price per kilometer was the main factor for calculating the ideal rates. This study was conducted to determine the effect of variations toll rates if enforced and their elasticity. Research [5]., Explains the use of language theory and automata to overcome problems with parking systems through a simulation using parking maps and state automata diagrams.

However, these studies are limited in theoretical dis cussion and non-toll road objects, because in this study the simulation was made to illustrate according to real conditions in the field. As a case study, the study was conducted on the Jakarta Inner Ring Road and the Jakarta Outer Ring Road. In this study a Stated Preference survey was conducted, and a number of simulations of traffic flow and revenue of toll road operators and road networks were carried out using SATURN software. The results of the study show that an increase in toll rates during peak hours will reduce toll road traffic volume and revenue. However, the effect of rising prices does not change the value of Volume Capacity Ratio (VCR) and Service Level significantly due to the value of time and high transportation needs and limited road capacity.

To illustrate the simulation, the process use the formal specification technique that is used to make a state diagram as a behavior model of a system. This state diagram will be the basis for defining tuples and designing the programflowchart later. The type of state diagramused is mealy machines with the concept of Non-Deterministic Finite Automata (NFA). With mealy machines the output will be released at each transition between states that occur based on the in put received and the previous state [8]. So, it can be concluded that NFA can be applied to solve this problem, because toll gates can have a lot of output, depending on what the user wants. This is proven by the success of the FSA used to design a map that can identify vehicle rates with a payment system based on the distance from the Tangerang-West Jakartatoll gate. With this research, providing an alternative toll road system and the right payment system so that it can streamline the cost of 
expenditure.

\section{Research Methods}

As a method of making a systemused is Iterative Model. This method has a match with the system to be made. This iterative model consists of plan initialization, planning, implementation, testing, evaluation and maintenance. Iterative Waterfall The model created can look like the image below:

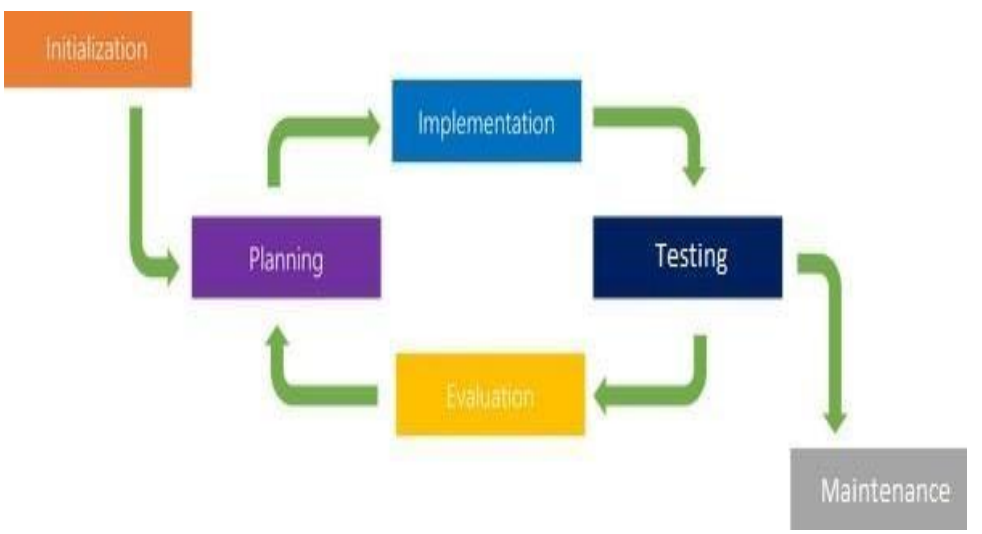

Fig. 1. Research Method: Iterative Waterfall Model [9]

\subsection{Plan Initialization}

This plan includes joint discussion with the research group, brainstorming problems and assessing the resources that will be used as an initial stage in the plan. This study examines the problem of uniformrates imposed on several tolls so that solutions will be discussed to resolve this problem by determining rates using a distance calculation system.

\subsection{Planning}

This planning stage includes the formulation of the problem, determining the needs in solving the problemand finding information in the form of sample data. In this study, the data found is the existence of flat fare as the main problem. So it can be resolved by the application of Finite State Automata, namely the concept of Non-Deterministic Finite Automata (NFA) for mapping as determining the distance of a vehicle traveled to determine the price of toll use services based on the distance traveled.

\subsection{Implementation}

In this implementation will be divided into 2 processes, namely: 


\subsubsection{State Diagram Mapping}

For making the state diagram, the Lucidchart programis used. The figure below shows the state diagram for mapping the Tangerang-West Jakarta toll road:

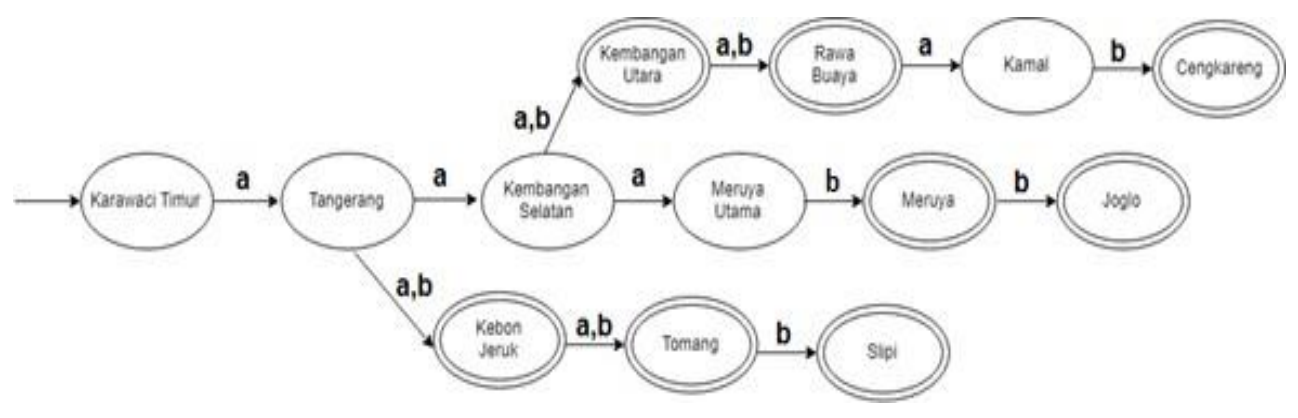

Fig. 2. Diagram State of Mapping on Tangerang to West Jakarta's Toll Road's

Information:

$\mathbf{Q}=\{$ Karawaci Timur, Tangerang, Kembangan Selatan, Meruya Utama, Meruya, Joglo, Kebon Jeruk, Tomang, Slipi, Kembangan Utara, Rawa Buaya, Kamal, Cengkareng \}

$\sum=\{a, b\}$

$\mathbf{S}=\{$ Karawaci Timur $\}$

$\mathbf{F}=\{$ Kembangan Utara, Rawa Buaya, Cengkareng, Kebon Jeruk, Tomang, Slipi, Meruya, Joglo $\}$

$\Delta=\{(($ Karawaci Timur, a)Tangerang), ((Tangerang, a)Kembangan Selatan) ((Tangerang, b)Kebon Jeruk), ((Kebon Jeruk, b)Tomang), ((Tomang, b)Slipi), ((Kembangan Selatan, a)Meruya Utama) ((Kembangan Selatan, b)Kembangan Utara), ((Meruya Utama, b)Meruya), ((Meruya, b)Joglo), ((Kembangan Utara, b)Rawa Buaya), ((Rawa Buaya, a)Kamal), ((Kamal, b)Cengkareng) \}

For alphabetical information, the set of input symbols that state what the driver is doing; (a) proceed to the toll gate, (b) exit the toll gate. As for the state statement stating the place / toll gate that is passed by the driver (Karawaci Timur) toll gate entering Karawaci Timur, (Tangerang) toll gate exit Tangerang, (Kembangan Selatan) toll gate exit Kembangan Selatan, (Meruya Utama) toll gate entrance Meruya Utama, (Meruya) Meruya exit toll gate, (Joglo) Joglo exit toll gate, (Kebon Jeruk) Kebon Jeruk exit toll gate, (Tomang) Tomang exit toll gate, (Slipi) Slipi exit toll gate, (North Kembangan) exit toll gate Kembangan Utara, (Rawa Buaya) toll gate exit Rawa 
Buaya, (Kamal) toll gate Kamal exit, (Cengkareng) toll gate exit Cengkareng.

Table 1. Transition Table on Tangerang to West Jakarta's Toll Road's

\begin{tabular}{|c|c|c|}
\hline$\Delta$ & $\mathbf{a}$ & $\bar{b}$ \\
\hline Karawaci Timur & Tangerang & $\varnothing$ \\
\hline Tangerang & Kembangan Selatan & Kebon Jeruk \\
\hline $\begin{array}{c}\text { Kembangan } \\
\text { Selatan }\end{array}$ & Meruya Utama & Kembangan Utara \\
\hline Meruya Utama & $\varnothing$ & Meruya \\
\hline Meruya & $\varnothing$ & Joglo \\
\hline Joglo & $\varnothing$ & $\varnothing$ \\
\hline Kebon Jeruk & $\varnothing$ & Tomang \\
\hline Tomang & $\varnothing$ & Slipi \\
\hline Slipi & $\varnothing$ & $\varnothing$ \\
\hline Kembangan Utara & $\varnothing$ & Rawa Buaya \\
\hline Rawa Buaya & Kamal & $\varnothing$ \\
\hline Kamal & $\varnothing$ & Cengkareng \\
\hline Cengkareng & $\varnothing$ & $\varnothing$ \\
\hline
\end{tabular}

Table 1 describes the state dis placement if there is input that is entered. For example, in Karawaci Timur state, it gets in put a, then it will move to state Tangerang, according to figure 2 . Then from state $\mathrm{S} 2$ it gets input a, it will move to Kembangan Selatan state. When you get input b it will come out in Kebon Jeruk state. When you get input $\mathrm{c}$ it will move to Kebon Jeruk state. And so on for how to read the transition fromanother state. The state transfer will be of value $\emptyset$ (Empty) if each input that is entered is not suitable. For example state $S 1$ if it gets input $b$, it will be worth $\varnothing$ 
(Empty). And so on for other states, which get inappropriate input.

\subsubsection{Payment System Testing}

If this plan is applied in the formof a flowchart using Raptor, examples are shown in figures 3 and 4.

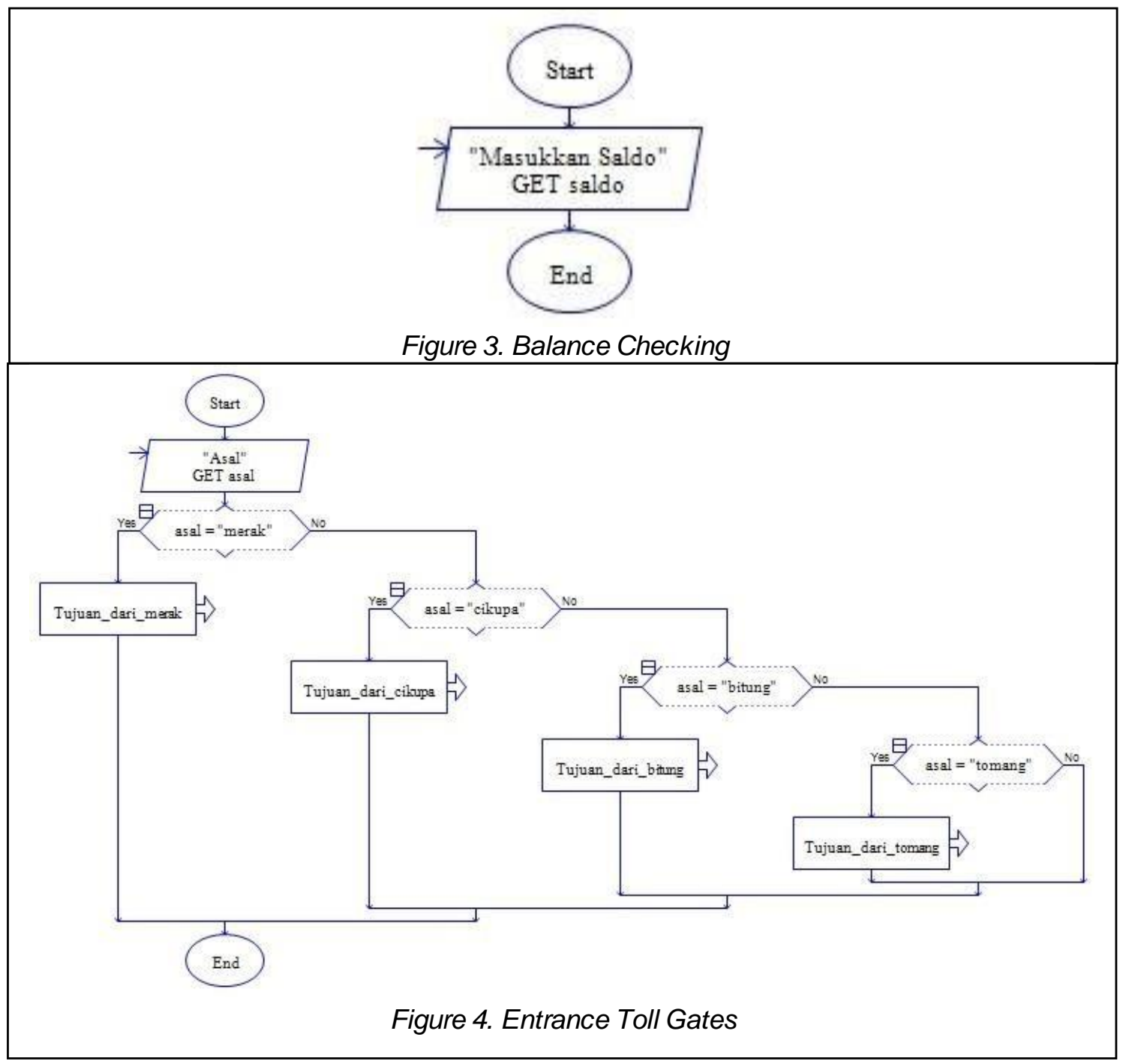


When entering the toll gate, driver tap the card to see the contents of the card balance. In this simulation the driverenters the toll road through Merak and has a destination to Bitung. Then the systemwill record the driver entrance tapping from Merak and when the driver tapping exits in Bitung, the system will calculate the distance the driver has traveled and display the fare, at the same time the system cuts the driver's balance as a form of payment.

\subsection{Testing}

With a flat rate, driver who have a destination that is not too far away, feel dis advantaged because the fare is the same as the distance between the toll entry and exit toll further. For example, with a flat rate, a driver who comes from Merak has a destination to Bitung, but the driver must continue to pay the same rate as the destination to Tomang. It will make riders spend more extravagantly. Therefore, the researchers created this toll rate system.

\subsection{Evaluation}

Aftergoing through several processes, the simulation using the Raptor application works well so that it can be as sessed more simply. In determining the rate, it can be considered more equitable than using a flat fare system. However, the drawback of the scenario test in 2.4 is that the system only calcu lates distances, does not take into account raw material for the toll road and does not take into account whether it is an elevated toll road or not.

\subsection{Maintenance}

The programis a simulation in the application phase that does not require periodic maintenance.

\section{Result and Discussions}

The results of this trial will be implemented using a programcreated using the Raptor application.

\subsection{How the Program Works}

At the start of the program, the driver will enter the toll gate. After that, the driver will be asked to do an entrance tapping card to activate the card. If the driver does not have a card then the driver must make a card in place. After that, driver can enter the toll gate. Before exiting the toll gate, driver are required to do a tapping card out. After tapping out, the driver can exit the toll gate. 


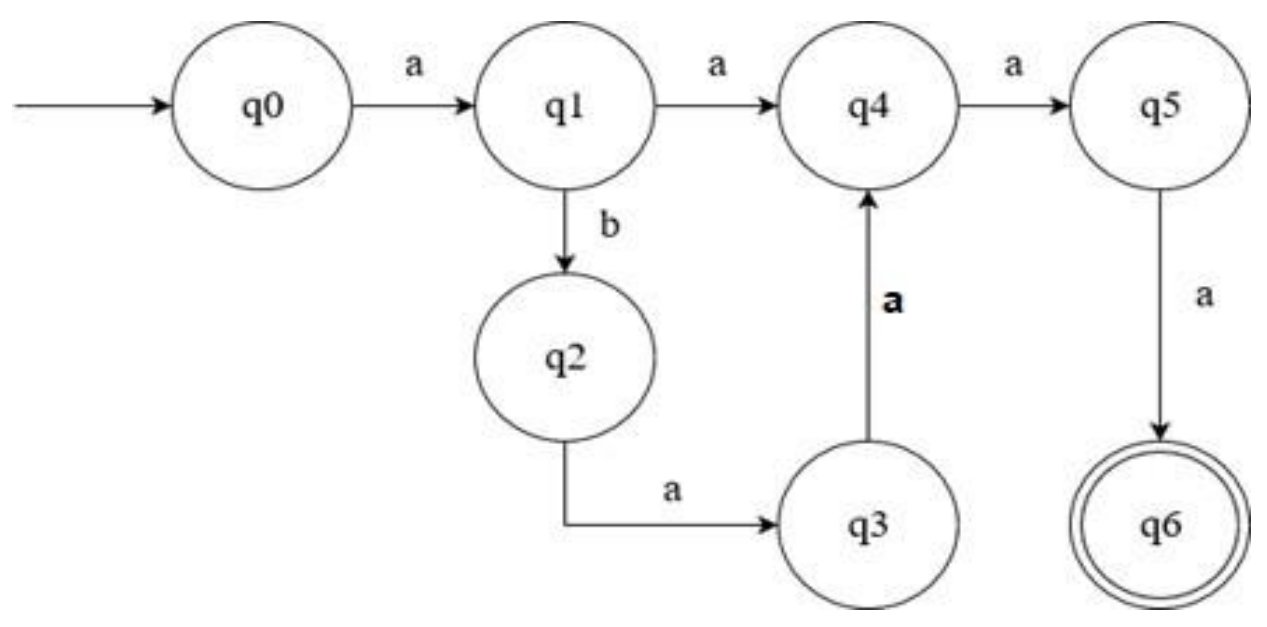

Fig. 5. State Diagram: The Process of Vehicle Activity

Keterangan:

$\mathbf{Q}=\{\mathrm{q} 0, \mathrm{q} 1, \mathrm{q} 2, \mathrm{q} 3, \mathrm{q} 4, \mathrm{q} 5, \mathrm{q} 6\}$

$\sum=\{a, b\}$

$\mathbf{S}=\{\mathrm{q} 0\}$

$\mathbf{F}=\{\mathrm{q} 6\}$

$\Delta=\{((\mathrm{q} 0, \mathrm{a}) \mathrm{q} 1),((\mathrm{q} 1, \mathrm{a}) \mathrm{q} 4)((\mathrm{q} 1, \mathrm{~b}) \mathrm{q} 2),((\mathrm{q} 2, \mathrm{a}) \mathrm{q} 3),((\mathrm{q} 3, \mathrm{a}) \mathrm{q} 4),((\mathrm{q} 4, \mathrm{a}) \mathrm{q} 5)((\mathrm{q} 5, \mathrm{a}) \mathrm{q} 6)\}$

For alphabetical information, the set of input symbols that state what the driver is doing; (a) continues to the next state without conditions, (b) continues to the next state with conditions.

In this state diagram, the machine has several states that symbolize the process, as follows: 
Table 2. Payment System

\begin{tabular}{|c|c|l|}
\hline No. & State & \multicolumn{1}{|c|}{ Description } \\
\hline 1 & $\mathrm{q} 0$ & Start State, Entrance Gate \\
\hline 2 & $\mathrm{q} 1$ & Tapping Card (Entrance) \\
\hline 3 & $\mathrm{q} 2$ & Do not have a card \\
\hline 4 & $\mathrm{q} 3$ & Make a card \\
\hline 5 & $\mathrm{q} 4$ & Enter the Gate \\
\hline 6 & $\mathrm{q} 5$ & Tapping Card Exit $)$ \\
\hline 7 & $\mathrm{q} 6$ & Exit the Gate \\
\hline
\end{tabular}

\subsection{Final Output}

The output display below is a display of the final payment system program that is run using the Raptor program. In the display below will issue information as below:

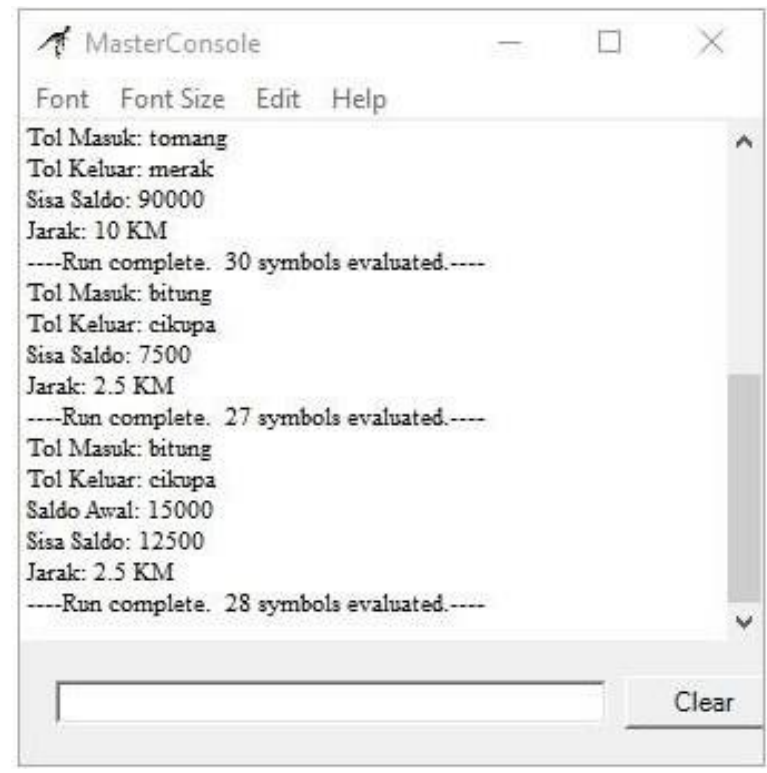

Fig. 6. Output

In Figure 6. Output results contain information on Entrance gate, Exit gate, Total Balance, Remaining Balance and Distance traveled by motorists from the inbound to the 
expressway.

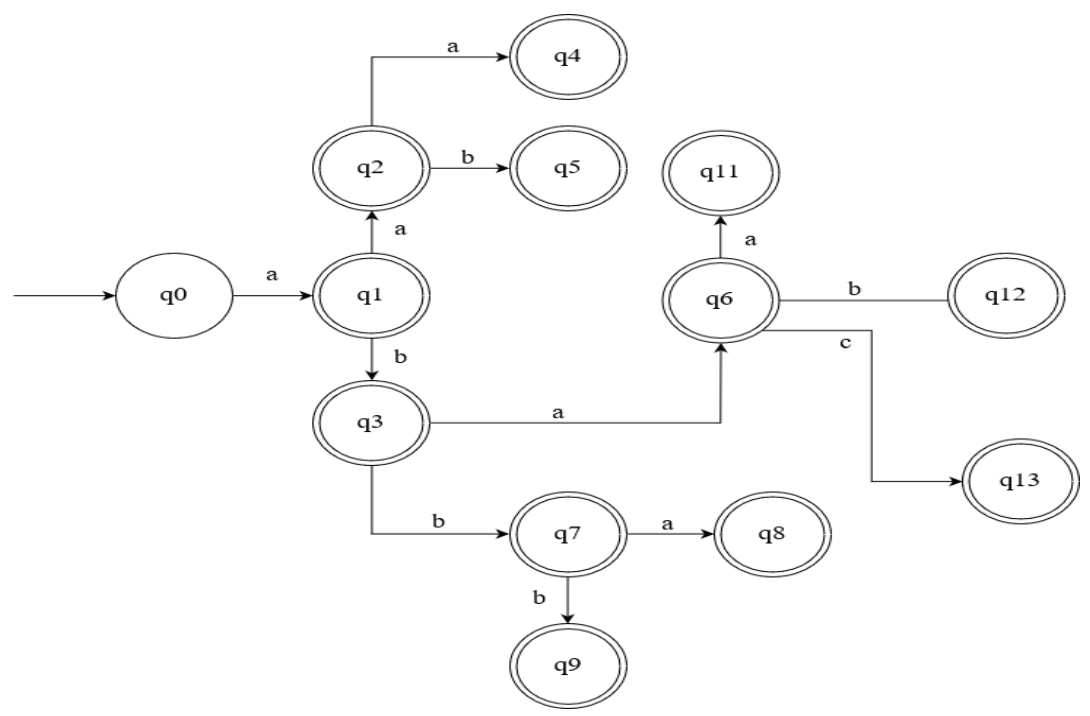

Fig. 7. Mapping System on Tangerang to West Jakarta's Toll Road's

Keterangan:

$\mathbf{Q}=\{\mathrm{q} 0, \mathrm{q} 1, \mathrm{q} 2, \mathrm{q} 3, \mathrm{q} 4, \mathrm{q} 5, \mathrm{q} 6, \mathrm{q} 7, \mathrm{q} 8, \mathrm{q} 9, \mathrm{q} 10, \mathrm{q} 11, \mathrm{q} 12, \mathrm{q} 13\}$

$\sum=\{\mathrm{a}, \mathrm{b}, \mathrm{c}\}$

$\mathbf{S}=\{\mathrm{q} 0\}$

$\mathbf{F}=\{\mathrm{q} 1, \mathrm{q} 2, \mathrm{q} 3, \mathrm{q} 4, \mathrm{q} 5, \mathrm{q} 6, \mathrm{q} 7, \mathrm{q} 8, \mathrm{q} 9, \mathrm{q} 10, \mathrm{q} 11, \mathrm{q} 12, \mathrm{q} 13\}$

$\Delta=\{((\mathrm{q} 0, \mathrm{a}) \mathrm{q} 1),((\mathrm{q} 1, \mathrm{a}) \mathrm{q} 2)((\mathrm{q} 1, \mathrm{~b}) \mathrm{q} 3),((\mathrm{q} 2, \mathrm{a}) \mathrm{q} 4)((\mathrm{q} 2, \mathrm{~b}) \mathrm{q} 5),((\mathrm{q} 3, \mathrm{a}) \mathrm{q} 6)((\mathrm{q} 3, \mathrm{~b}) \mathrm{q} 7)$, $((\mathrm{q} 6, \mathrm{a}) \mathrm{q} 11)((\mathrm{q} 6, \mathrm{~b}) \mathrm{q} 12)((\mathrm{q} 6, \mathrm{c}) \mathrm{q} 13),((\mathrm{q} 7, \mathrm{a}) \mathrm{q} 8)((\mathrm{q} 7, \mathrm{~b}) \mathrm{q} 9)\}$

For alphabetical information, the set of input symbols that state what the driver is doing; (a) exit toll gate / pass toll gate, (b) exit toll gate / pass toll gate and (c) exit toll gate.

In this state diagram, the machine has several states that symbolize the process, as follows 
Table 3. Mapping on Tangerang to West Jakarta's Toll Road's

\begin{tabular}{|c|c|l|}
\hline No. & State & \multicolumn{1}{|c|}{ Description } \\
\hline 1 & $\mathrm{q} 0$ & Start State, Entrance Gate Karawaci Timur \\
\hline 2 & $\mathrm{q} 1$ & Exit Gate Tangerang \\
\hline 3 & $\mathrm{q} 2$ & Exit Gate Kebon Jeruk \\
\hline 4 & $\mathrm{q} 3$ & Exit Gate Kembangan Selatan \\
\hline 5 & $\mathrm{q} 4$ & Exit Gate Tomang \\
\hline 6 & $\mathrm{q} 5$ & Exit Gate Slipi \\
\hline 7 & $\mathrm{q} 6$ & Exit Gate Kembangan Utara \\
\hline 8 & $\mathrm{q} 7$ & Exit Gate Meruya Utama \\
\hline 9 & $\mathrm{q} 8$ & Exit Gate Meruya \\
\hline 10 & $\mathrm{q} 9$ & Exit Gate Joglo \\
\hline 11 & $\mathrm{q} 11$ & Exit Gate Rawa Buaya \\
\hline 12 & $\mathrm{q} 12$ & Exit Gate Kamal \\
\hline 13 & $\mathrm{q} 13$ & Exit Gate Cengkareng \\
\hline
\end{tabular}

After going through several processes, the simulation using the Raptor application works well so that it can be assessed more simply. In determining the rates, it can be considered more equitable than using a flat fare system. However, the drawback of the scenario test in 2.4 is that the system only calculates distances, does not take into account raw material for the toll road and does not take into account whether it is an elevated toll road or not. There are drawbacks to this system, which at the time of manufacture requires a lot of costs. In Figure 5, there is a card tapping process where this process will cause the vehicle queue so that the whole system has not eliminated the problem.

\section{Conclusions and Recommendation}

After passing through the series of tests, it can be concluded that the concept of NonDeterministic Finite Automata can be used for mapping and simulating the payment system for the Tangerang - West Jakarta toll road based on the distance traveled. The concept of Non- Deterministic Finite Automata will accept input and will be translated in machine language. Test simulations have been carried out with a flow chart that is run using a raptor, the results run well and in accordance with what is expected. Based on the results of simulations that have been done through testing with the Raptor application, it 
can be concluded that the rates measured by the distance of the vehicle entering through the toll gate will be far more efficient but because there is a card tapping process, this system can interfere with the smooth use of the toll road. But if it is seen in terms of the magnitude of the benefits it can be concluded that toll rates based on distance will provide fairness to all toll road users because the toll rate is calculated based on a predetermined distance so that this system can be considered quite useful and better than flat fare.

Suggestions for the next research is that toll users will not need to do card tapping when entering toll roads, because sensors at the toll gate will automatically read the card balance contained in the vehicle and when toll exits users also do not need to do card tapping because the balance is automatically cut according to toll rates.

\section{References}

[1] Djaslim, V. Putra and A. Kusnadi, "Implementation of Non-Deterministic Finite Automata for Tenses Identification in English Translator," New Media Technology, vol. 1, no. 1, pp. 27-37, 2014.

[2] S. D. Ariamsah, "ANALISA TARIF JALAN TOL JALAN TOL BERDASARKAN PENDEKATAN WILLINGNES TO PAY (WTP) DAN ABILITY TO PAY (ATP).," TUGAS AKHIR, 2015.

[3] J. Marga, "Investor Summit \& Capital Market Expo," Jasa Marga, 2015.

[4] Mauren Ninata Shiky, Ronald Jeferson Simbolon, Ismiyati, Eko Yulipriyono, "ANALISIS KARAKTERISTIK VOLUME LALU LINTAS DI JALAN TOL SEMARANG," Jurnal Karya Teknik Sipil, vol. 5, pp. 94-104, 2016.

[5] J. A. Pelupessy, "Penerapan Finite State Automata Pada Pemetaan Sistem Parkiran Kendaraan Motor di Kampus UKSW Salatiga," Skripsi, 2016.

[6] Muhammad Arief Fatkhurrahman, Wahyul Amien Syafei, Darjat, "PERANCANGAN PROTOTIPE SISTEM GERBANG TOL CERDAS BERBASIS RFID DAN NOTIFIKASI PEMBAYARAN VIA SOCIAL MESSENGER," Transient, vol. 6, p. 4, 2017.

[7] S. Q. Murhany, "ANALISIS TARIF JALAN TOL BAKAUHENI - BANDAR LAMPUNG PADA RUAS BAKAUHENI- TERBANGGI BESAR BERDASARKAN PENDEKATAN ATP DAN WTP," Tesis, 2018. 
[8] Benny Richardson, Kevin Hendy, Ventryshia Andiyani, Wilson Philips, "Penerapan Konsep Non-Deterministic Finite Automata (NFA) pada Aplikasi Simulasi Mesin Kopi Vending," Jurnal Informatika Universitas Pamulang, vol. 4, p. 1, 2019.

[9] N. B. Ruparelia, "Software Development Lifecycle Models," ACM SIGSOFT Software Engineering Notes, vol. 35, no. 3, pp. 9-10, 2010. 